\title{
Application of Balanced Scorecard in the Enterprise Performance Evaluation
}

\author{
Huiping Huang \\ Zao Zhuang College \\ Zao Zhuang, Shan dong Province, 277160, China \\ xjhhp@126.com
}

\author{
Huimin Huang \\ Bing Tuan College \\ Wu Jia Qu, Xin Jiang, 831300, China \\ 471134372@qq.com
}

\begin{abstract}
The present study is designed to describe the application of Balanced Scorecard in Jinan Iron and Steel Company. Performance evaluation system is constituted by the financial quantitative performance evaluation and management performance qualitative evaluation. Balanced Scorecard is Integration of Non-financial indicators and financial indicators. Balanced Scorecard implements process: strategy being taken into action; Communication and exchanging and incentives linked. Balanced Scorecard implements process in Jinan Iron and Steel Co. includes the level of corporate finance; the level of corporate cus tomers; the level of internal business processes and levels of corporate learning and innovation. The level of corporate customers can be divided into the consolidation of market share; the rate of high-quality project; customer satisfaction; supplier Satisfaction. The other three can be also refined into a plurality of non-financial indicators. We show that the use of the Balanced Scorecard improves the profitability and operational capability of Jinan Iron and Steel.
\end{abstract}

Keywords-Non-financial Indicators; Balanced Scorecard; Enterprise Performance Evaluation; Jinan Iron and Steel Co.

\section{INTRODUCTION}

With the changing competitive environment, the traditional system based solely on financial indicators of enterprise performance evaluation has become increasingly unsuited to the needs of management. Non-financial indicators are more and more attention in the theory and practice as a useful supplement of financial evaluation [1].

\section{ENTERPRISE PERFORMANCE EVAlUAtion SySTEM}

\section{A. Performance Evaluation Overview.}

Performance Evaluation refers to made a comprehensive evaluation to the overall business performance and operational efficiency of enterprises. Enterprises make objective, fair and accurate and comprehensive evaluation within a certain period of operational efficiency and operator performance [2].

\section{B. Performance Evaluation System.}

Performance Evaluation System is constituted by the financial quantitative performance evaluation and management performance qualitative evaluation. After determining the specific indicators, and then were assigned different weights, making it a complete index system [3].

Financial performances indicators, based on a quantitative evaluation of the functional of the indicators, are divided into basic indicators and the modification indices. Overall, nonfinancial indicators are a useful complement to the traditional financial indicators [4]. So due to defect of traditional financial evaluation in the evaluation of corporate performance, Kaplan and Norton and performance evaluate leading 12 companies in the project for a period of one year after the study. Combined with non-financial indicators, they proposed the concept of the Balanced Scorecard in 1992.

\section{Integration of Non-financial indicators and financial indicators - Balanced Scorecard.}

1) Balanced Scorecard Overview: Balanced Scorecard is a comprehensive performance evaluation system, integrated into the financial and non-financial indicators. It is through four levels of index mutual causality, the Inter-financial, customer, internal business processes, learning and innovation-driven to show the organization's strategy architecture [5]. It achieves performance evaluation in order to promote implementation of the strategy. The results illustrate the financial measures arising from the actions taken, as well as to improve the evaluation activities, through customer satisfaction, internal processes and organizational innovation and performance indicators. It is the future financial performance indicators Performance propeller. Balanced Scorecard does not replace financial indicators, but to supplement them. Balanced Scorecard, as an advanced enterprise evaluation system, has its own unique process of implementation.

2) Balanced Scorecard implementation process: First, strategy is taken into action. Companies will build their own strategic objectives, aimed at the introduction of the Balanced Scorecard strategic business target segments. The first step of the strategy into action is in the implementation of the Balanced Scorecard. According to industry characteristics and the company's strategy, enterprises design of the financial indicators, such as cost margins, accounts receivable turnover and inventory turnover rate, but also covers a number of key non-financial indicators, such as customer satisfaction, energy equipment utilization and staff satisfaction degree. 
Second, communication and exchanging. Balanced Scorecard has two key: one is the "number one" paying attention; the second is communication. In implementing the Balanced Scorecard, corporate executives should personally and form an action team.

Third incentives linked. Employees are the core of enterprise development. Employee satisfaction is crucial, in order that employees accept this totally different measurement tool, the Balanced Scorecard system must motivate by employees. Enterprises establish a selection, evaluation, incentive and restraint mechanisms for enterprise employees in accordance with the development. The Board evaluates company personnel performance on an annual, and decides to pay classification based on results.

\section{BALANCED SCORECARD StUdy ON JinAN IRON AND STEEL}

\section{A. Background introducing the Balanced Scorecard of Jinan} Iron and Steel.

BSC is a universal significance and broad prospect operability strategic management tool. Jinan Iron and Steel Co., for example, is the introduction of the Balanced Scorecard in the global financial crisis of the environment as part of its performance evaluation and examination system. In 2008, worldwide outbreak of the financial crisis, the second half of
2008 due to the global financial turmoil, Jinan Iron and Steel Co., also appeared a significant decline in revenue earnings. Therefore, in order to gain a firm foothold in the competitive market, the company's management sets up a Balanced Scorecard as its performance evaluation system. They hope through mutual complementary non-financial indicators and financial indicators in order to motivate employees to achieve the production, improve the company's performance, while achieving sustainable development of the company.

\section{B. Balanced Scorecard process implemented in Jinan Iron and Steel Co.}

First, the level of corporate finance. Balanced Scorecard retains the contents of the financial aspects of the arrangement, because of convergence of the direct financial indicators and corporate long-term objectives. Long-term goal of the company is almost always financial in nature. Appropriate financial indicators can reflect the performance of the company. Jinan

In Iron and Steel Co., it is set up financial perspective of BSC in accordance with the principle. It will also pay linked to business performance and staff. Financial perspective of financial strategy of Balanced

Scorecard in Jinan Iron and Steel is as shown in Table 1.

TABLE I.

FINANCIAL STRATEGY OF BALANCED SCORECARD IN JINAN IRON AND STEEL

\begin{tabular}{|c|c|c|c|}
\hline $\begin{array}{l}\text { Strategic } \\
\text { themes }\end{array}$ & $\begin{array}{l}\text { Level } \\
\text { Of enterprise Performance }\end{array}$ & Index & Measures \\
\hline \multirow{5}{*}{$\begin{array}{l}\text { With more } \\
\text { financial } \\
\text { indicators } \\
\text { than } \\
\text { Competitors } \\
\text { to return } \\
\text { enterprise }\end{array}$} & \multirow{5}{*}{$\begin{array}{l}\text { Performance level of each } \\
\text { interest group subsidiaries and } \\
\text { various departments, improving } \\
\text { profitability, and linking to staff } \\
\text { salaries }\end{array}$} & Cost margins & $\begin{array}{l}\text { To reduce expenses, to increase revenue and to improve } \\
\text { profitability growth }\end{array}$ \\
\hline & & $\begin{array}{l}\text { Accounts } \\
\text { receivable } \\
\text { turnover ratio }\end{array}$ & $\begin{array}{l}\text { To Enhance construction quality, to maintain good } \\
\text { relations with customers and to adjust credit policy }\end{array}$ \\
\hline & & $\begin{array}{l}\text { Inventory } \\
\text { turnover }\end{array}$ & $\begin{array}{l}\text { To reduce inventory production, the rational allocation, } \\
\text { focusing on structure and to reduce inventory turnover } \\
\text { days }\end{array}$ \\
\hline & & $\begin{array}{l}\text { Net asset } \\
\text { turnover }\end{array}$ & $\begin{array}{l}\text { To improve profitability, moderate distribution of cash } \\
\text { dividends and to reduce debt }\end{array}$ \\
\hline & & $\begin{array}{l}\text { The main } \\
\text { business } \\
\text { gross profit } \\
\text { margin }\end{array}$ & To strengthen cost control and cost management \\
\hline
\end{tabular}

Second, the level of corporate customers. Customer level reflects the changes in the outside world. Only we continue to meet customer needs and realize the value of products, can the company's financial resources achieve sustained growth? In fact, companies focus on customer care market and marketing strategies. Undoubtedly, the enterprise market strategy will affect the financial targets. Market competitiveness can be diagnosed by studying the impact of marketing strategies for financial goals. In Jinan Iron and Steel Co., customer level of BSC is as shown in Table 2. 
TABLE II. CUSTOMER STRATEGY OF BALANCED SCORECARD IN JINAN IRON AND STEEL

\begin{tabular}{|c|c|c|c|}
\hline $\begin{array}{l}\text { Strategic } \\
\text { themes }\end{array}$ & $\begin{array}{l}\text { Performance level of } \\
\text { objective corporate }\end{array}$ & Indicators & Measures \\
\hline \multirow{4}{*}{$\begin{array}{l}\text { To make } \\
\text { business easy } \\
\text { to carry out } \\
\text { and } \\
\text { achievement of } \\
\text { our } \\
\text { commitment }\end{array}$} & \multirow{4}{*}{$\begin{array}{l}\text { To open up the } \\
\text { target market, to } \\
\text { hold existing market, } \\
\text { to let } \\
\text { customer satisfaction } \\
\text { and enterprise } \\
\text { sustainable growth }\end{array}$} & Supplier Satisfaction & $\begin{array}{l}\text { Not satisfied with the information for suppliers, the } \\
\text { implementation of special measures. such as "improving } \\
\text { largest supplier loyalty," "delivery process convenience" } \\
\text { and many other aspects }\end{array}$ \\
\hline & & $\begin{array}{l}\text { The consolidation of } \\
\text { market share, }\end{array}$ & $\begin{array}{l}\text { The railway market share, to expand the non-rail market } \\
\text { share and to expand business networks in the Midwest }\end{array}$ \\
\hline & & Customer Satisfaction & $\begin{array}{l}\text { To establish cross-sect oral "three orders accreditation" } \\
\text { system, to balance and improve technology ability and to } \\
\text { achieve production-order }\end{array}$ \\
\hline & & $\begin{array}{l}\text { The rate of high- } \\
\text { quality project }\end{array}$ & $\begin{array}{l}\text { To establish an idea of "start is excellent, one that is } \\
\text { excellent"and with quality supervisors }\end{array}$ \\
\hline \multicolumn{3}{|c|}{$\begin{array}{l}\text { Third, the level of internal business processes. Business } \\
\text { orocesses within the enterprise level, the business goal is to } \\
\text { olve the "what we are good at". In order to attract and retain } \\
\text { zustomers in the target market, meet the requirements of the } \\
\text { nterests of shareholders to maximize, managers must focus on } \\
\text { hose maximum internal processes which affect customer } \\
\text { atisfaction and the achievement of the organization's financial } \\
\text { soals. }\end{array}$} & $\begin{array}{l}\text { inancial performance appraisal emphasized that responsibility } \\
\text { or control and improvement of existing centers and } \\
\text { epartments. But simply to control and improve financial } \\
\text { erformance which is difficult to make business become the } \\
\text { lost powerful company in the market. To achieve and } \\
\text { taintain a competitive advantage, it is necessary for } \\
\text { nterprises to innovation, quality, and increasing productivity, } \\
\text { educing costs, supporting the product, marketing strategy and } \\
\text { chieving the company's financial goals. In Jinan Iron and Steel }\end{array}$ \\
\hline \multicolumn{3}{|c|}{$\begin{array}{l}\text { Internal business process indicators best illustrate the } \\
\text { fference between BSC and financial performance evaluation. }\end{array}$} & $\begin{array}{l}\text { o., internal business process level of BSC is as shown in } \\
\text { able } 3 \text {. }\end{array}$ \\
\hline
\end{tabular}

TABLE III. INTERNAL BUSINESS PROCESS ST RATEGY OF BALANCED SCORECARD IN JINAN IRON AND STEEL

\begin{tabular}{|c|c|c|c|}
\hline Strategic themes & $\begin{array}{l}\text { Performance } \\
\text { Level of } \\
\text { objective } \\
\text { corporate }\end{array}$ & Indicators & Measures \\
\hline \multirow{5}{*}{$\begin{array}{l}\text { To establish } \\
\text { focused on } \\
\text { market strategy } \\
\text { and to support } \\
\text { cost-effective for } \\
\text { research and } \\
\text { development }\end{array}$} & \multirow{5}{*}{$\begin{array}{l}\text { To optimize the } \\
\text { product structure, } \\
\text { to improve } \\
\text { profitability, to } \\
\text { focus on } \\
\text { efficiency, to } \\
\text { focus on } \\
\text { marketing and } \\
\text { product } \\
\text { development, to } \\
\text { strengthen } \\
\text { management } \\
\text { and to improve } \\
\text { the health, safety } \\
\text { and environment }\end{array}$} & $\begin{array}{l}\text { The time for } \\
\text { discussion of } \\
\text { new projects } \\
\text { with customers }\end{array}$ & $\begin{array}{l}\text { To reflect the needs of customers and Unconstrained to } \\
\text { communicate with customers }\end{array}$ \\
\hline & & $\begin{array}{l}\text { Energy } \\
\text { utilization }\end{array}$ & $\begin{array}{l}\text { To research and development of clean energy conversion of Steel, } \\
\text { efficient and clean use of secondary energy and to improve } \\
\text { equipment utilization }\end{array}$ \\
\hline & & $\begin{array}{l}\text { The level of core } \\
\text { competitiveness }\end{array}$ & $\begin{array}{l}\text { Important initiatives of to enhance the core competitiveness as } \\
\text { structural adjustment, to change the company from "production- } \\
\text { scale" to "varieties efficiency"and to optimize the original fuel } \\
\text { structure, energy structure and product mix }\end{array}$ \\
\hline & & $\begin{array}{l}\text { the degree of } \\
\text { hygiene in the } \\
\text { production }\end{array}$ & $\begin{array}{l}\text { Vigorously to promote clean production; to increase technology, } \\
\text { equipment, product structure adjustment and to strengthen the } \\
\text { comprehensive governance of environmental }\end{array}$ \\
\hline & & $\begin{array}{l}\text { Production } \\
\text { intensification }\end{array}$ & $\begin{array}{l}\text { The more balanced in the ratio between upstream and } \\
\text { downstream production, energy and power, auxiliary facilities, to } \\
\text { create an integrated industrial chain, and further to optimize the } \\
\text { process structure; to concern of cost, to eliminate backward } \\
\text { technology, and to improve production intensification }\end{array}$ \\
\hline
\end{tabular}

Fourth, levels of corporate learning and innovation. Enterprises must establish a long-term growth and innovation infrastructure. Customer aspects and internal business processes establish a key factor in terms of current and future success. But today's technology alone and production capacity, companies can't achieve long-term objectives of their customers and internal business processes. To fill these gaps, 
companies must invest in order to improve staff's ability and performance requirements of enterprise management. Staff should be trained constantly learning new technology, new knowledge, and constantly strengthen individual capacity to adapt to the needs of the times. For example, in Jinan Iron and Steel Co., it sets up a situation for their own learning and innovation dimensions of the Balanced Scorecard and establishes good incentives to stimulate the enthusiasm of the staff.

In Jinan Iron and Steel internal business process of Balanced Scorecard is as shown in Table 4.

TABLE IV. LEARNING AND INNOVATION STRATEGY OF BALANCED SCORECARD IN JINAN IRON AND STEEL

\begin{tabular}{|c|c|c|c|}
\hline $\begin{array}{l}\text { Strategic } \\
\text { themes }\end{array}$ & $\begin{array}{l}\text { Performance level of } \\
\text { objective corporate }\end{array}$ & Indicators & Measures \\
\hline \multirow{5}{*}{$\begin{array}{l}\text { By training } \\
\text { employees } \\
\text { and creating a } \\
\text { good } \\
\text { performance of } \\
\text { enterprises }\end{array}$} & \multirow{5}{*}{$\begin{array}{l}\text { Through strategic re- } \\
\text { training to improve } \\
\text { the level of innovation } \\
\text { and the ability of } \\
\text { employees and to } \\
\text { establish a good } \\
\text { incentive mechanism }\end{array}$} & $\begin{array}{l}\text { Employee } \\
\text { Satisfaction }\end{array}$ & $\begin{array}{l}\text { To strengthen communication with staff, further to reform and } \\
\text { improve the wage distribution model; to build employee } \\
\text { performance appraisal system, the implementation of talent } \\
\text { development strategy and to increase distribution and incentive }\end{array}$ \\
\hline & & $\begin{array}{l}\text { The number of } \\
\text { innovative } \\
\text { projects }\end{array}$ & $\begin{array}{l}\text { To establish an incentive mechanism, to encourage innovation, and } \\
\text { innovation are rewarded }\end{array}$ \\
\hline & & $\begin{array}{l}\text { The number of } \\
\text { rationalization } \\
\text { proposals }\end{array}$ & $\begin{array}{l}\text { To set up "four in one" operation mode of trade unions, employee } \\
\text { participation, professional research and feasibility studies, to } \\
\text { establish employee files, employees recommend a return visit card, } \\
\text { employee suggestion feedback cards and to call for rationalization } \\
\text { proposals and adopted }\end{array}$ \\
\hline & & $\begin{array}{l}\text { Occupational } \\
\text { Safety and } \\
\text { productivity }\end{array}$ & $\begin{array}{l}\text { To adhere to the "safe production", to sign letters of responsibility } \\
\text { for security objectives with employees and safe production and } \\
\text { environmental control targets completion rate of } 100 \%\end{array}$ \\
\hline & & $\begin{array}{l}\text { Employee } \\
\text { retention }\end{array}$ & $\begin{array}{l}\text { To establish a "difficult employee records"and "Autumn student } \\
\text { electronic files"and to build a harmonious enterprise, to leave } \\
\text { people with feelings, career treatment }\end{array}$ \\
\hline
\end{tabular}

These four indicators of enterprise Balanced Scorecard forms a complete system. Only the business continue to improve internal business processes, innovation and ability continuously improve and staff quality and service quality continue to progress, do customer make satisfaction continues to improve. These will increase their strength in the market competition, expand market share and achieve financial goals. Ultimately they make shareholders satisfied.

\section{CONCLUSION}

From the case of Jinan Iron and Steel, we can get the following revelation:

First, although the trend of enterprise performance evaluation system is a Non-financial indicator evaluation system, but it does not mean that we abandon the traditional financial indicators evaluation system [6]. For example, Jinan Iron and Steel Co., appropriately choose financial indicators. From the perspective of incentives, Jinan Iron and Steel also set up employee satisfaction and employee retention rate and other indicators.

Second, in order to accurately measure the management activities of the enterprise, strategic goals must be clear; specifically what the results will reach.

In the implementation of the Balanced Scorecard process, Jinan Iron and Steel Co., Ltd. clarifies its strategic objectives and set specific performance measures in four areas of financial, customer, internal processes and employees.
Third, most of the performance evaluation system is a strategic implementation tool, how to implement the decision in the top leadership of the company. Such as Jinan Iron and Steel Co. executives have command personally promote the implementation of the Balanced Scorecard, so Balanced Scorecard has achieved remarkable results.

Fourth, many companies have realized that the characteristics of human resources, human resources are as the most critical factor in the modern enterprise important strategic resource and enterprise development. The incentives are an important part of human resources.

\section{REFERENCES}

[1] Xu Jun Zhang, "Outline of non-financial information in financial report", Finance and Accounting Monthly, 2003,pp. 6-7(In Chinese).

[2] Hongyun Han and ZhiLan Zhang, "Non-financial indicators of the performance Evaluation”, Xi'an University of Architecture and Technology, 2006(In Chinese).

[3] Junhui Sun, "Construction and Improvement of Enterprise Performance Evaluation System”, The field of Finance and Economics, 2012, pp. 1617(In Chinese).

[4] Yimin $\mathrm{Hu}$, "The choose of non-financial indicators - correlation analysis of the value”, Study on Finance and Economics, 2001, pp. 13-14(In Chinese).

[5] Kaplan and Norton Balanced. "Scorecard Strategy Practice”. Beijing: Ren min University of China Press, 2009,pp. 22-23(In Chinese).

[6] Guang Tang. "Overview of non-financial indicators of evaluating corporate value”, Finance and Accounting Monthly, 2003,pp. 32-33 (In Chinese). 